\title{
BIOINDICATION OF AEROTECHNOGENIC POLLUTION OF AGRICULTURAL LANDSCAPES CAUSED BY THE ACTIVITIES OF INDUSTRIAL HUBS
}

\author{
TETIANA FEDONIUK $\bowtie$, ROMAN FEDONIUK, TETIANA KLYMENKO, OLEH POLISHCHUK, ANDRII PITSIL
}

Polissia National University, Stary Boulevard 7, Zhytomyr, 10008, Ukraine; e-mail: tanyavasiluk2015@gmail.com

$\bowtie$ Corresponding author

Received: 12 January 2020 / Accepted: 5 July 2020

Abstract

Fedoniuk T., Fedoniuk R., Klymenko T., Polishchuk O., Pitsil A.: Bioindication of aerotechnogenic pollution of agricultural landscapes caused by the activities of industrial hubs. Ekológia (Bratislava), Vol. 40, No. 2, p. 115-123, 2021

\begin{abstract}
The article provides the assessment of the levels of aerotechnogenic pollution caused by the emissions from stationary pollution sources of industrial agglomerations in Zhytomyr, taking into account climatic conditions that affect the dispersion and accumulation of pollutants in soils and vegetation cover of surrounding agricultural landscapes. The examination of dust accumulated on the surface of leaves showed that it contains high concentrations of $\mathrm{Mn}, \mathrm{Cr}, \mathrm{Pb}, \mathrm{Ni}$, and $\mathrm{Cu}$. The bioindication method with the use of white-tip radishes was applied to estimate the extent of aerotechnogenic pollution. The results of the investigation testified to the high informativeness of the offered test objects. The indexes of soil saturation with heavy metals indicated the presence of intensive processes of their accumulation. As a consequence, this territory became unsuitable for agricultural production. The inhibition of growth of radish roots identified the toxicity level of the investigated technogenic substrates as medium and higher than average. Also, there is inverse close correlation relationship between the distance from the emission source and the soil phytotoxicity indicators in all the investigated directions.
\end{abstract}

Key words: soil saturation, prevailing wind, heavy metals, indicators, phytotoxicological indices.

\section{Introduction}

The Directive 2008/50/EC of the European Parliament on ambient air quality and cleaner air for Europe establishes the need to reduce pollution to the levels that minimize adverse effects on human health and the environment as a whole, to improve the control and assessment of air quality, including pollutant accumulation, and to make the information publicly available. The problem of atmospheric air pollution in the Zhytomyr region is acute, though the region is not an industrial center. However, as a large number of industrial enterprises are located in a small area, it causes an exacerbation of the ecological crisis within individual landscapes. Dust coming from surrounding areas provokes the accumulation of significant amounts of pollutants in soils, water, and other components of agro-systems.

\section{Analysis of the latest research and papers}

One of the most informative methods for assessing the state of the environment and the impact of negative environmental factors on biota are biotesting methods. There are convenient because they make it possible to evaluate the integrated influence of factors, they are sensitive even to small changes and are convenient for laboratory modeling, they optimally reproduce environmental conditions, and they are simple and easily accessible for regular analysis.

Many groups of test objects are known (garden cress, whitetip radish, mustard, etc.). They are extremely informative when used for soil biotesting (Jandová et al., 2020). Test objects make it possible to detect toxic compounds in soil samples relatively quickly without the need to conduct a series of chemical tests and analyzes.

A rather informative method for the diagnostics of environmental toxicity is the method of using test objects of plant systems (Fedorchak, 2020; Yusypiva, Miasoid, 2019). Maňkovská and Oszlányi (2010) obtained results on atmospheric deposition of 45 elements in Báb research sites using the moss biomonitoring technique. Miroshnychenko and Kryvytska (2016) used maize and garden radish plants as test objects to study the degree of phytotoxicity of soil in the city of Mariupol at different levels of their contamination with heavy metals and mineral salts. The influence of cement production was analyzed in the paper of Zymaroieva et al. (2020). In several of our previous papers, we highlighted the features of migration of pollutants within the studied agricultural landscape (Romanchuck et al., 2017a,b, 2018; Fedoniuk et al., 2019, 2020; Zymaroieva et al., 2021; Fedonyuk et al., 2020). A number of authors used aquatic plants, garden cress, radish, and other plants to determine the influence of poly-element contamination of soddy-podzolic soil (Martin et

(c) The Author(s) 2021. This is an open access article distributed under the terms of the CC BY-NC-ND license.

https://content.sciendo.com/view/journals/eko/eko-overview.xml 


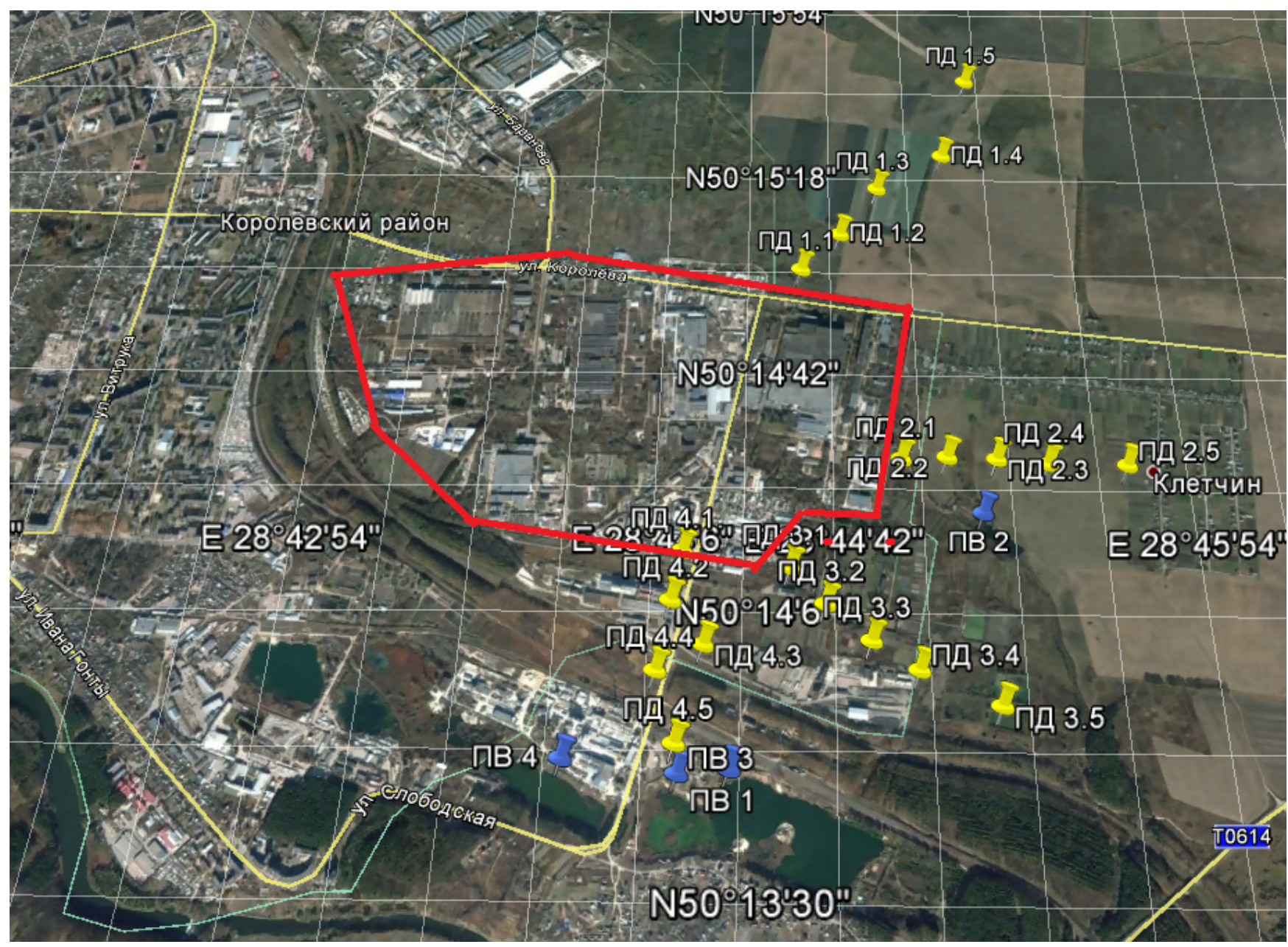

Fig. 1. The map showing the location of observation points.

al., 2006; Rudin et al., 2018; Gusev, Vashukevich, 2016; Gyekye, 2013; Favas et al., 2012). The toxicity of various substances to plants was highlighted in many papers which determined the phytotoxicity of plumbum and cuprum (Dayton et al., 2006; McBride, Martínez, 2000), the integrated phytotoxicity of zinc, titanium, and nickel oxides (Jośko, Oleszczuk, 2013), and a common phytotoxic effect of cadmium and mercury (Cao et al., 2007; Baderna et al., 2015). In our research, we analyzed the content of heavy metals in soil, which come in large quantities with the industrial dust from the eastern industrial hub in Zhytomyr and also their phytotoxic effect on radish sprouts.

\section{Identifying previously unaddressed issues of the gen- eral problem}

The Directive 2008/50/EC of the European Parliament on ambient air quality and cleaner air for Europe stipulates that monitoring of air quality and its impact on the components of agricultural landscape shall be carried out within individual agricultural landscapes. In Ukraine, the system which monitors the migration of pollutants in the chain 'air-soil-plants' is not applied at all, and the research data come down to detecting how much certain groups of substances in soil and air exceed MAC (Maximum allowable concentration). In view of this, if the extent of aerotechnogenic pollution caused by the activities of industrial hubs on the components of agricultural landscapes is determined, this will make it possible to identify the patterns of behavior of the components of dust pollution within the components of agricultural landscapes.

\section{Material and methods}

The research of aerotechnogenic pollution was carried out at different distances $(100-2000 \mathrm{~m})$ from the East industrial hub in Zhytomyr in the direction of prevailing wind.

The first route is laid in the direction of the prevailing northwest wind, that is, the southeastern part of the area of the emission source. Dark gray bleached light loamy loess soil prevails here. The second direction is laid in the easterly one, where dark gray bleached light loamy loess soil prevails. The third direction is northeast from the source of technology related emission; here, black earth bleached light loamy loess soil dominates. In this direction, the wind is not as strong as in the southeast and north directions, but this area is between the areas of increased technology-related emission and may be subject to repeated technogenic pollution due to the runoff. The fourth direction 
is north from the source of technology-related emission; here, black earth bleached light loamy loess soil dominates.

For the purpose of investigation into the composition of the dust, leaves of woody plants were selected in the area under investigation and the dust accumulated on their surface was washed away with distilled water. The method of filtration was used to obtain the powder, which was tested for the content of toxic impurities. The method of powder X-ray diffraction was used to check the mineral composition in the laboratory of the scientific industrial enterprise 'Engler'. The dried dust samples underwent autoclave microwave decomposition using the MWS2 system (Berghof, Germany). Samples weighing $0.2 \mathrm{~g}$ and $8 \mathrm{ml}$ of $\mathrm{HNO} 3$ and $36 \%$ solution of $\mathrm{H}_{2} \mathrm{O}_{2}$ in a ratio of $1: 1$ were placed in the fluoroplastic autoclave DAP-60K (volume $60 \mathrm{ml}$ ). Then, the samples were sealed, and they underwent a three-stage microwave decomposition at a temperature of $120^{\circ} \mathrm{C}$ at the first stage, $180{ }^{\circ} \mathrm{C}$ at the second stage, and $200{ }^{\circ} \mathrm{C}$ at the third stage. The solutions were analyzed on an Agilent 7500A Inductively Coupled Plasma Mass Spectrometer (COI-MS).

The toxicity of technologenically contaminated substrates and the sensitivity of the classical laboratory test objects, whitetip red radish (Raphanus sativus var. Radicula Pers.), were determined using the method of O.A. Berestetskyi (Berestetskyi, 1971). The method is based on the germination of seeds of model plant species on different substrates. In this case, soil extracts obtained from soil sampled at observation points were used as substrates. Varieties KBK and Ilka of the white-tip red radish (Raphanus sativus var. Radicula Pers.) were used for the research.

The phytotoxic effect (PhE, \%) was determined as a percentage of the length of the root system by the formula (Lozanovskaya, 1998):

$$
P h \mathrm{E}=\frac{L_{o}-L_{x}}{L_{o}} * 100,
$$

where Lo is the average root length of the plant grown in the control medium, and Lx is the average root length of a plant grown under the influence of a toxic factor. Substrate toxicity was assessed on a five-point scale (Table 1).

The phytotest was carried out for three years in succession (from 2016 to 2018) in a three-time repeat with the soils sampled for the analysis on the content of heavy metals at the previous stage of the scientific investigation.

\section{Results}

The plot under study is rectangular and has an area of 1475.189 ha. Interpolation, which uses the IDW method (inverse distance weighing) within the area where samples were selected, made it possible to select sites with different contents (Fig. 1). The highest content $>3 \mathrm{MAC}$ was obtained on an area of 60.714 ha, which is $4.12 \%$ of the territory. The content from 2 to $3 \mathrm{MAC}$ was observed on the area of 911.927 ha, $61.82 \%$. Low level of contamination from 1 to 2 was observed on the area of 487.1010
Table 1. The scale of toxicity levels of soil by the plant test systems (Dzhura et al., 2006).

\begin{tabular}{|l|l|}
\hline $\begin{array}{l}\text { The levels of inhibition of growth } \\
\text { (phytotoxic effect), \% }\end{array}$ & Toxicity level \\
\hline $0-20$ & Absent or low \\
\hline $20.1-40$ & Average \\
\hline $40.1-60$ & Above average \\
\hline $60.1-80$ & High \\
\hline $80.1-100$ & Maximum \\
\hline
\end{tabular}

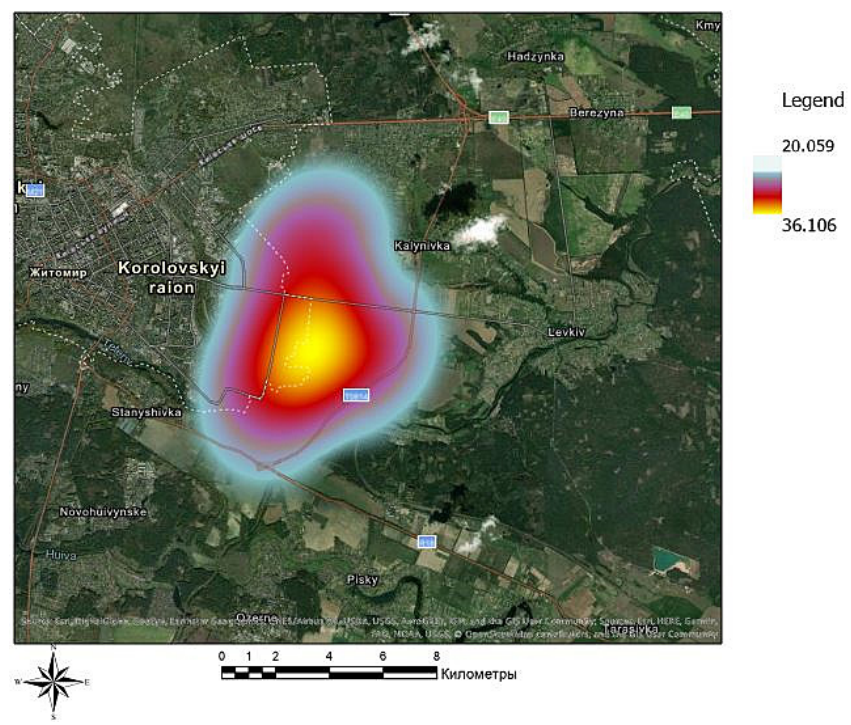

Fig. 2. Interpolation of the aerotechnogenic pollution of the territory of the eastern industrial hub in Zhytomyr (Ukraine) with the IDW method.

ha, $33.01 \%$, and the low content $<1$ MAC on the area of 15.538 ha, $1.05 \%$ (Fig. 2).

As the results of the investigation showed, the main measures aimed at improving the environmental state of agricultural landscapes should be aimed at macro-scale placement of measuring stationery points. In the territories in close proximity to the Eastern industrial hub, stationary measuring points should be located in the southeast, east, and south directions of the Eastern industrial hub.

The emissions of heavy metals with non-localized dust were calculated for the last ten years; they are as follows: $\mathrm{Mn}, 33158 ; \mathrm{Zn}$, 3687; Ni, 4604; Cu, 7736; Cr, $42364 \mathrm{~kg}$. Sixty-two percent of the annual emissions of heavy metals, which amounts to $5752.5 \mathrm{~kg}$, fall on the period of active vegetation of plants (April-September).

Examination of dust accumulated on the leaf surface showed that it contained high concentrations of $\mathrm{Mn}, \mathrm{Cr}, \mathrm{Pb}, \mathrm{Ni}$, and $\mathrm{Cu}$ (Table 2).

Table 2. Content of heavy metals in dust, $\mathrm{M}+\mathrm{m}, \mathrm{mg} / \mathrm{kg}$.

\begin{tabular}{|c|c|c|c|c|c|c|c|c|}
\hline \multirow[b]{2}{*}{ Type of dust components } & \multicolumn{8}{|c|}{ Cations } \\
\hline & $\mathrm{Mn}^{2+}$ & $\mathrm{Zn}^{2+}$ & $\mathbf{P b}^{2+}$ & $\mathrm{Cd}^{2+}$ & $\mathbf{N i}^{2+}$ & $\mathrm{Co}^{2+}$ & $\mathrm{Cu}^{2+}$ & $\mathrm{Cr}^{2+}$ \\
\hline Inorganic dust $(n=5)$ & $1349 \pm 65$ & $163 \pm 25$ & $311 \pm 35$ & $3 \pm 0.3$ & $235 \pm 21$ & $15 \pm 2$ & $387 \pm 17$ & $156 \pm 28$ \\
\hline
\end{tabular}




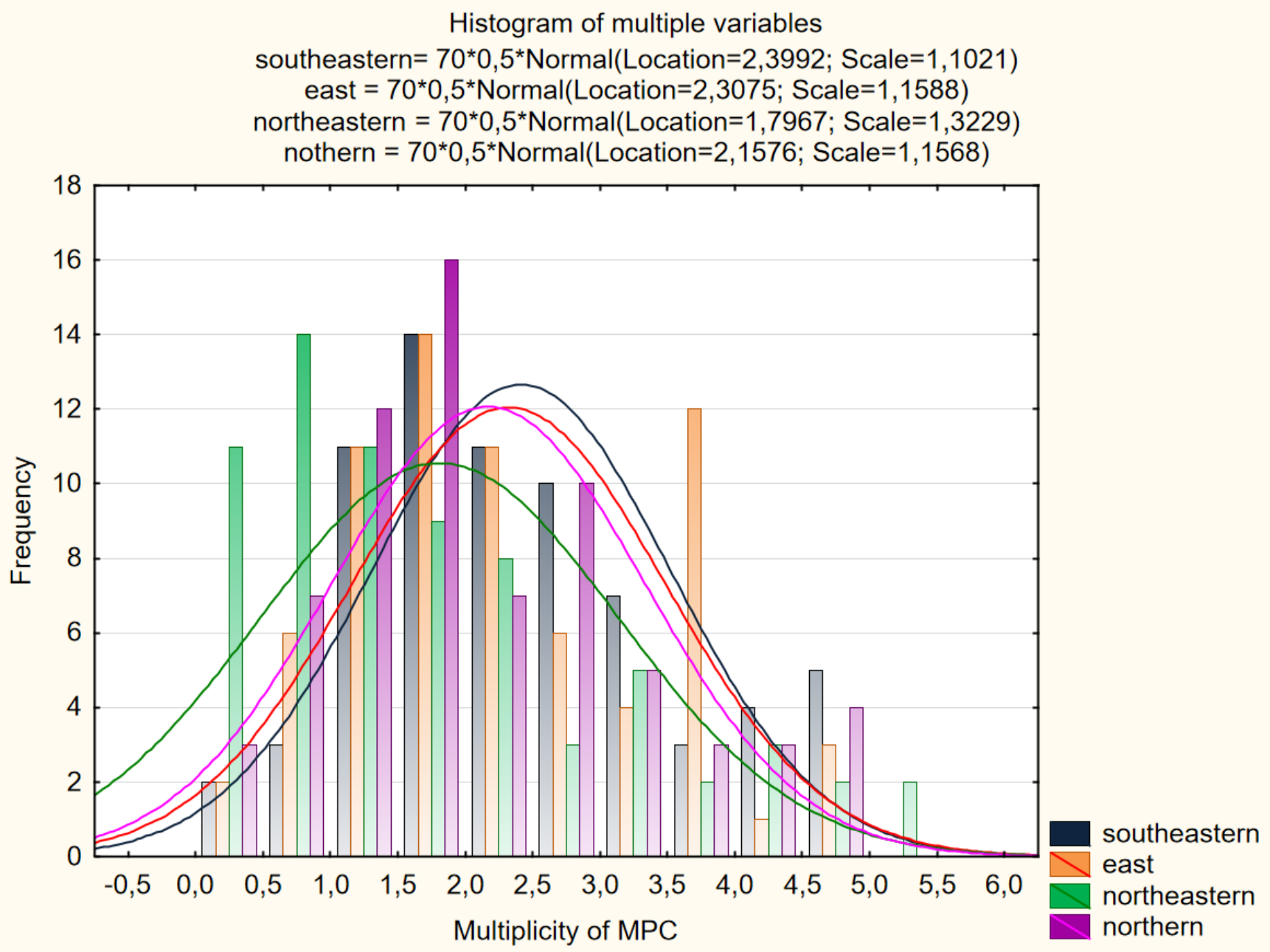

Fig. 3. Histograms of the distribution of critical values of the MAC exceedances of dust content in the air under the influence of prevailing winds of the east industrial hub.

The inorganic dust, which is a result of such production, accumulates on the surface of soil, trees, and grassland vegetation. It was found out that the basic component of dust is the crystalline phase of quartz. Impurities of other phases are also found in the samples, and the detection of which was exceptionally challenging because of the predominance of quartz peaks. However, it was noted that the impurity of the other crystalline phases was different in all samples, indicating the heterogeneous origin of the materials under analysis. Thus, this confirms the integrated effect of the enterprises within the same territory.

The lowest frequency of occurrence of exceedances of critical points was noted in the direction of southwest wind, which is characterized by the lowest recurrence for the area (location = 1.7967; scale $=1.3229$ ) (Fig. 3). The strongest dispersion of dust by the distance from the emission source was noted for the most intense and recurrent northwest wind (location $=2.3992$; scale $=$ 1.1021). When the dust streams are dispersed with this wind, the occurrence of critical MAC exceedance points increases by 0.6 units; if the dust is dispersed with the east wind, it increases by 0.51 units and in case of the southern wind by 0.36 units.

Data obtained after the examination of the qualitative and quantitative composition of soil pollutants in the Eastern indus- trial hub signal about significant risks to agriculture and health. In order to assess poly-element anomalies, which characterize the availability of various pollutants in the soil, we used the indexes of soil saturation with heavy metals. They are brought to the territory of the investigated agricultural landscapes in the largest amounts together with inorganic dust. The data obtained testify to the fact of soil degradation due to the pollution from the industrial hub.

The southeastern direction was characterized by the highest rates of total soil contamination. Two particularly critical zones were noted, this is the area at $200-250 \mathrm{~m}$, where the maximum index of soil saturation with elements was indicated, which is indicative of the intensive processes of accumulation of pollutants. In this area, the maximum concentrations of cuprum content were observed. It is mainly dispersed in the form of coarse particles, and thus is accumulated closer to the source of emission. The second critical area in this direction is the area $1.5-2 \mathrm{~km}$ from the source of emission. This indicates that fine particles, which contain a large amount of manganese, zinc, and plumbum, are of key importance in soil contamination in this direction. The indexes of soil saturation with the elements are indicative of the intensive accumulation processes. This territory is not suitable 
Table 3. Hazard assessment of soil contamination by the total pollution indicator (according to GOST (State Standard) 17.4.3.06-86 Nature Conservation. Soil. General requirements to soil classification according to the influence of chemical pollutants on them).

\begin{tabular}{|c|c|c|c|c|c|c|}
\hline $\begin{array}{l}\text { Distance from } \\
\text { the source of } \\
\text { emission }\end{array}$ & \begin{tabular}{|c|} 
Index of \\
soil satura- \\
tion with \\
elements, $\mathrm{I}_{\mathrm{el}}$
\end{tabular} & $\begin{array}{l}\text { Total } \\
\text { indica- } \\
\text { tor, } \mathrm{Zc}\end{array}$ & Category of soil contamination & $\begin{array}{l}\text { Content of } \\
\text { elements } \\
\text { to MAC }\end{array}$ & $\begin{array}{l}\text { Possibility to be used } \\
\text { in agriculture }\end{array}$ & $\begin{array}{l}\text { Change in the pub- } \\
\text { lic health record in } \\
\text { the polluted area }\end{array}$ \\
\hline \multicolumn{7}{|c|}{ Northwestern } \\
\hline $100-150$ & 4.0884 & 27.1970 & Moderately hazardous & \multirow{8}{*}{$\begin{array}{c}\text { Above MAC } \\
\text { but not higher } \\
\text { than translo- } \\
\text { cation factor }\end{array}$} & \multirow{8}{*}{$\begin{array}{l}\text { Cultivation of any } \\
\text { crops provided there } \\
\text { is a quality control of } \\
\text { plant products }\end{array}$} & \multirow{8}{*}{$\begin{array}{l}\text { Increased number } \\
\text { of general diseases }\end{array}$} \\
\hline $200-250$ & 4.9437 & 32.0901 & Hazardous & & & \\
\hline $251-350$ & 3.7816 & 25.9585 & Moderately hazardous & & & \\
\hline $351-600$ & 4.3193 & 28.5180 & Moderately hazardous & & & \\
\hline $601-900$ & 4.1976 & 25.3475 & Moderately hazardous & & & \\
\hline $901-1100$ & 4.6675 & 29.9228 & Moderately hazardous & & & \\
\hline $1101-1300$ & 4.8331 & 29.1361 & Moderately hazardous & & & \\
\hline $1301-1600$ & 4.8529 & 30.7279 & Moderately hazardous & & & \\
\hline $1601-1900$ & 5.1996 & 33.9877 & Hazardous & \multirow{2}{*}{$\begin{array}{l}\text { Above MAC } \\
\text { but not higher } \\
\text { than translo- } \\
\text { cation factor }\end{array}$} & \multirow[b]{2}{*}{$\begin{array}{l}\text { Cultivation of in- } \\
\text { dustrial crops with- } \\
\text { out obtaining food } \\
\text { products and fodders } \\
\text { from them. Inclusion } \\
\text { of concentrators of } \\
\text { elements-pollutants }\end{array}$} & \multirow[b]{2}{*}{$\begin{array}{l}\text { Increased number } \\
\text { of general diseases } \\
\text { and the number } \\
\text { of sickly children } \\
\text { and children with } \\
\text { chronic diseases, } \\
\text { disorders of cardio- } \\
\text { vascular system }\end{array}$} \\
\hline $1901-2150$ & 5.1099 & 36.1059 & Hazardous & & & \\
\hline \multicolumn{7}{|c|}{ Eastern } \\
\hline $100-150$ & 4.5083 & 24.8893 & Moderately hazardous & \multirow{10}{*}{$\begin{array}{l}\text { Above MAC } \\
\text { but not higher } \\
\text { than translo- } \\
\text { cation factor }\end{array}$} & \multirow{10}{*}{$\begin{array}{l}\text { Cultivation of any } \\
\text { crops provided there } \\
\text { is a quality control of } \\
\text { plant products }\end{array}$} & \multirow{10}{*}{$\begin{array}{l}\text { Increased number } \\
\text { of general diseases }\end{array}$} \\
\hline $200-250$ & 4.5063 & 26.8310 & Moderately hazardous & & & \\
\hline $251-350$ & 4.8036 & 26.7356 & Moderately hazardous & & & \\
\hline $351-600$ & 3.9494 & 24.7970 & Moderately hazardous & & & \\
\hline $601-900$ & 4.0756 & 27.1502 & Moderately hazardous & & & \\
\hline $901-1100$ & 4.0801 & 25.2954 & Moderately hazardous & & & \\
\hline $1101-1300$ & 4.5855 & 29.8431 & Moderately hazardous & & & \\
\hline $1301-1600$ & 4.3173 & 29.4929 & Moderately hazardous & & & \\
\hline $1601-1900$ & 4.7453 & 30.7524 & Moderately hazardous & & & \\
\hline $1901-2150$ & 4.1523 & 30.3798 & Moderately hazardous & & & \\
\hline \multicolumn{7}{|c|}{ Northeastern } \\
\hline $100-150$ & 3.5830 & 21.3625 & Moderately hazardous & \multirow{10}{*}{$\begin{array}{c}\text { Above MAC } \\
\text { but not higher } \\
\text { than translo- } \\
\text { cation factor }\end{array}$} & \multirow{10}{*}{$\begin{array}{l}\text { Cultivation of any } \\
\text { crops provided there } \\
\text { is a quality control of } \\
\text { plant products }\end{array}$} & \multirow{10}{*}{$\begin{array}{l}\text { Increased number } \\
\text { of general diseases }\end{array}$} \\
\hline $200-250$ & 3.3766 & 20.0590 & Moderately hazardous & & & \\
\hline $251-350$ & 3.8073 & 21.5496 & Moderately hazardous & & & \\
\hline $351-600$ & 3.8861 & 24.6260 & Moderately hazardous & & & \\
\hline $601-900$ & 4.1634 & 25.2589 & Moderately hazardous & & & \\
\hline $901-1100$ & 4.0911 & 25.5189 & Moderately hazardous & & & \\
\hline $1101-1300$ & 4.3416 & 27.5852 & Moderately hazardous & & & \\
\hline $1301-1600$ & 4.4573 & 28.4682 & Moderately hazardous & & & \\
\hline $1601-1900$ & 4.6712 & 30.9446 & Moderately hazardous & & & \\
\hline $1901-2150$ & 3.1717 & 26.3152 & Moderately hazardous & & & \\
\hline \multicolumn{7}{|c|}{ Northern } \\
\hline $100-150$ & 2.9710 & 20.7583 & Moderately hazardous & \multirow{10}{*}{$\begin{array}{c}\text { Above MAC } \\
\text { but not higher } \\
\text { than translo- } \\
\text { cation factor }\end{array}$} & \multirow{10}{*}{$\begin{array}{l}\text { Cultivation of any } \\
\text { crops provided there } \\
\text { is a quality control of } \\
\text { plant products }\end{array}$} & \multirow{10}{*}{$\begin{array}{l}\text { Increased number } \\
\text { of general diseases }\end{array}$} \\
\hline $200-250$ & 3.5793 & 23.7635 & Moderately hazardous & & & \\
\hline $251-350$ & 3.5242 & 23.3521 & Moderately hazardous & & & \\
\hline $351-600$ & 3.5557 & 23.7127 & Moderately hazardous & & & \\
\hline $601-900$ & 3.9651 & 25.9525 & Moderately hazardous & & & \\
\hline $901-1100$ & 3.9844 & 25.9764 & Moderately hazardous & & & \\
\hline $1101-1300$ & 3.8624 & 25.8868 & Moderately hazardous & & & \\
\hline $1301-1600$ & 4.4208 & 29.1434 & Moderately hazardous & & & \\
\hline $1601-1900$ & 4.1969 & 28.6448 & Moderately hazardous & & & \\
\hline $1901-2150$ & 3.7143 & 29.2294 & Moderately hazardous & & & \\
\hline
\end{tabular}




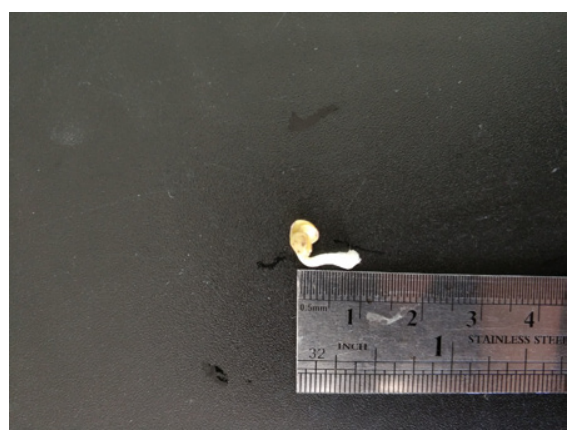

margin

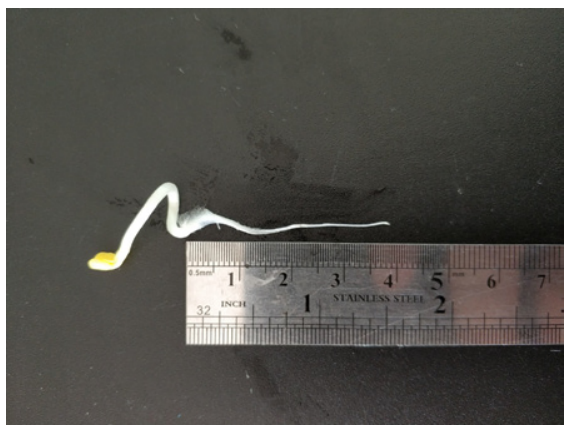

500

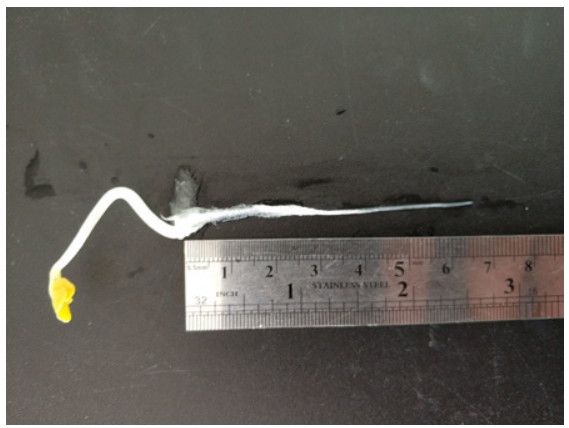

1250

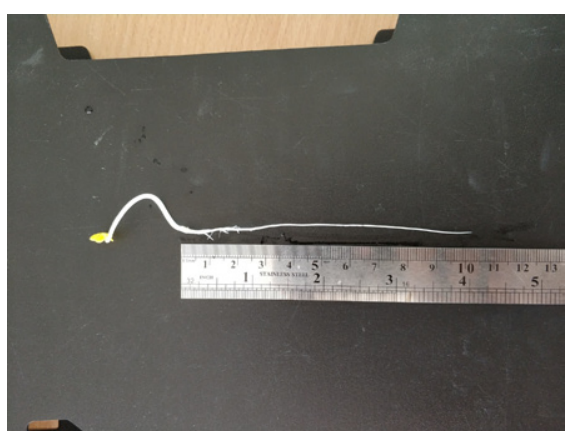

2000

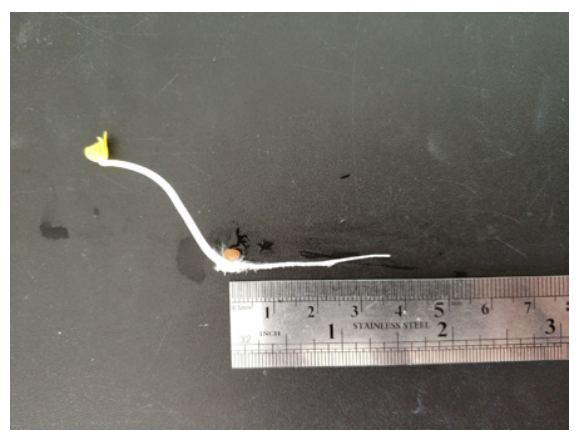

100

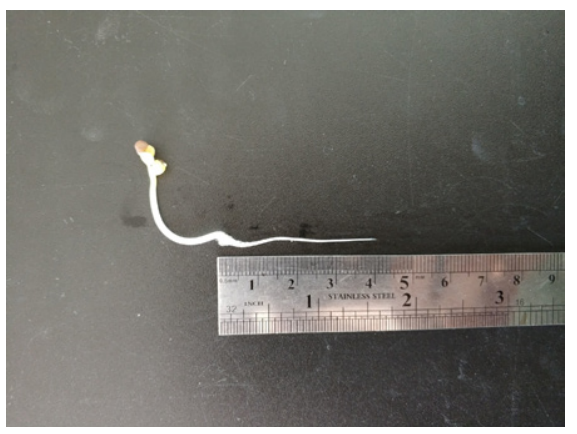

750

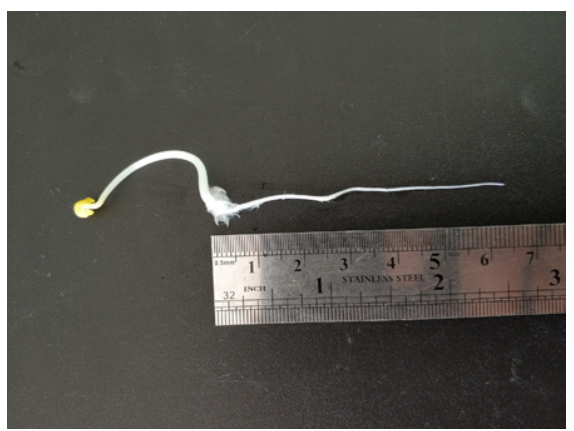

1500

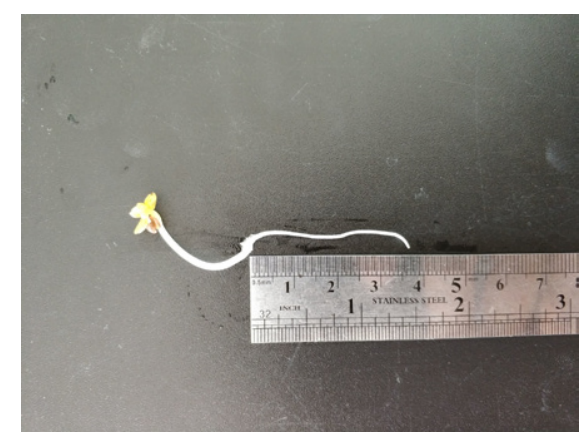

250

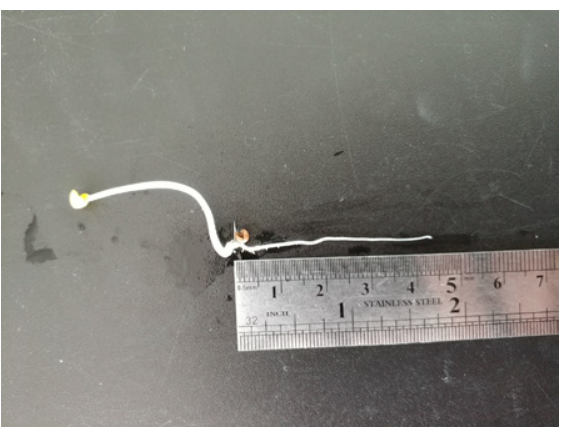

1000

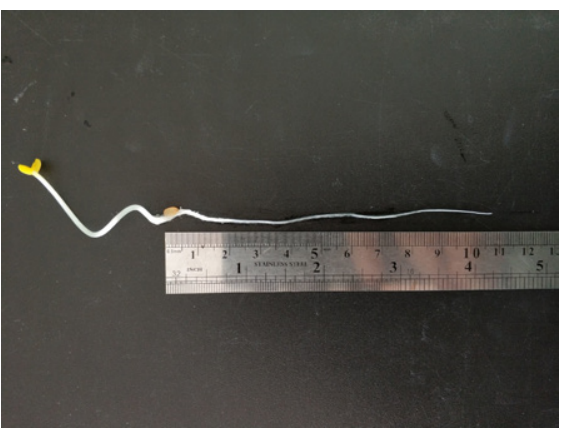

1750

Fig. 4. Biometric indicators of sprouts of radish roots grown on water extracts of anthropogenically transformed soil of the East industrial hub.

Distance from the source of emission, m:southeastern: $\mathrm{y}=1.5521+0.0011^{\star} \mathrm{x} ; \mathrm{r}=0.9400 ; \mathrm{p}=0.00005 ; \mathrm{r} 2=0.8836$

Distance from the source of emission, m:eastern:

$\mathrm{y}=1.7878+0.0011^{\star} \mathrm{x} ; \mathrm{r}=0.9775 ; \mathrm{p}=0.00000 ; \mathrm{r} 2=0.9555$

Distance from the source of emission, m:northeastern: $\mathrm{y}=2.0087+0.001^{\star} \mathrm{x} ; \mathrm{r}=0.9136 ; \mathrm{p}=0.0002 ; \mathrm{r} 2=0.8346$

Distance from the source of emission, m:northern:

$\mathrm{y}=2.1017+0.001^{\star} \mathrm{x} ; \mathrm{r}=0.9524 ; \mathrm{p}=0.00002 ; \mathrm{r} 2=0.9071$

for agricultural production, only for industrial crops. Such levels of contamination can lead to an increase in the number of diseases and an increase in the number of frequently ill children and children with chronic diseases, disorders of the functional state of the cardiovascular system. It should be noted that at a distance of $2.0-2.5 \mathrm{~km}$ from the industrial hub, the territory of the settlement of Klitchyn is located. Its population is about 560 people, and there are private plots of residents of other villages of the Levkiv village council. Subsistence farming is one of the most common methods of producing vegetables, potatoes, berries, etc. Taking into account the above, all products obtained in this territory must be subjected to strict sanitary control (Table 3 ).

In the eastern, northeastern and northern direction, there was a similar trend towards the increase in the contamination 


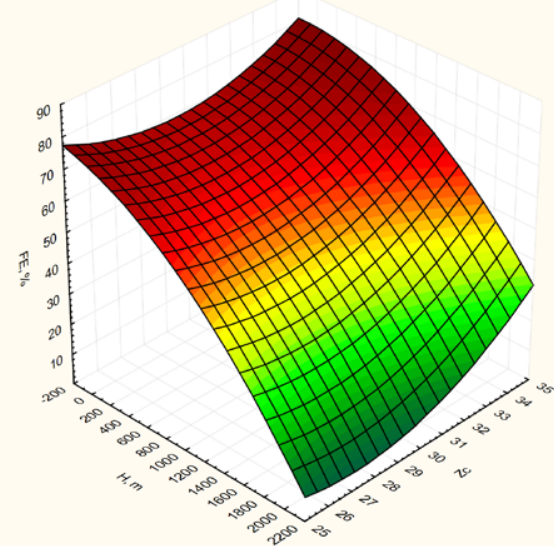

a

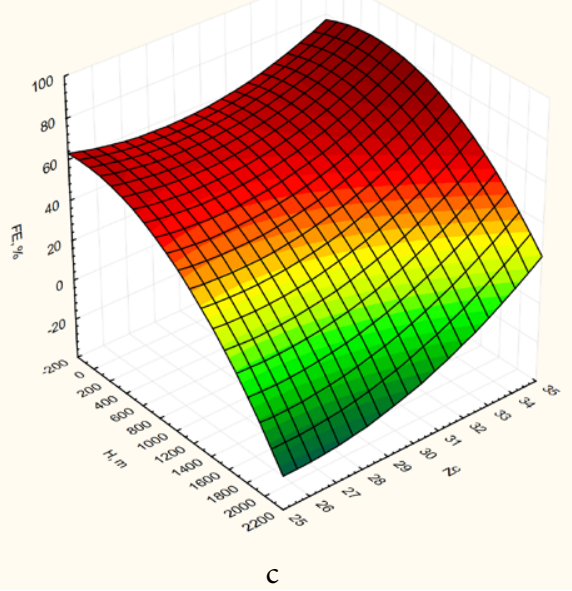

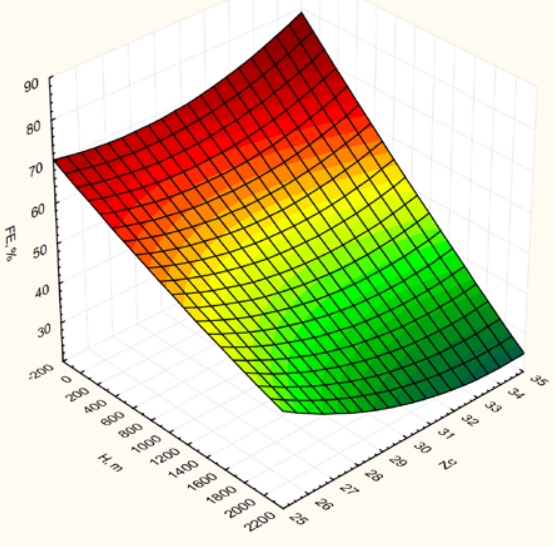

$\mathrm{b}$

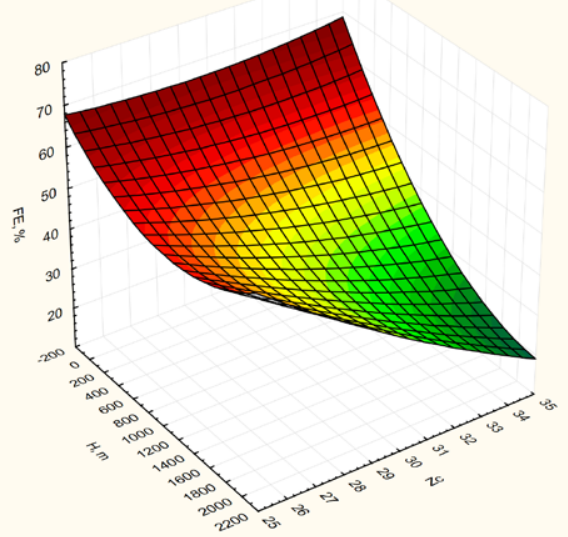

d

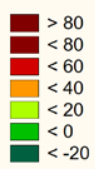

Fig. 5. Levels of inhibition of growth processes (phytotoxic effect) at different levels of soil toxicity (length of radish $\mathrm{sprouts}\left(\mathrm{Ph} \mathrm{E}_{\mathrm{B}} \%\right)$ according to the scale of Dzhura et al. (2006).

a) Southeastern $=429.774-0.0328^{\star} x-24.6576^{\star} y-8.7331 E-6^{*} x^{*} x+0.0009^{*} x^{*} y+0.4196^{\star} y^{\star} y$

b) Eastern $=253.0383+0.0161^{\star} \mathrm{x}-13.1283^{\star} \mathrm{y}+9.1511 \mathrm{E}-7^{\star} \mathrm{x}^{\star} \mathrm{x}-0.0012^{\star} \mathrm{x}^{\star} \mathrm{y}+0.229^{\star} \mathrm{y}^{\star} \mathrm{y}$

c) Northeastern $=459.7646-0.0359^{\star} x-28.3824^{\star} y-1.6988 E-5^{\star} x^{\star} x+0.0014^{\star} x^{\star} y+0.501^{\star} y^{\star} y$

d) Northern $=149.8652+0.0276^{\star} x-5.7134^{\star} y+7.9906 E-6^{\star} x^{\star} x-0.0018^{\star} x^{\star} y+0.0907^{\star} y^{\star} y$

levels over a distance of more than $1500 \mathrm{~m}$, which indicates that the largest amount of pollutants come in the form of fine dust. Indexes of soil saturation virtually throughout the territory in the eastern $(3.9494 \ldots 4.8036)$, the northeastern $(3.1717 \ldots$ 4.6712) and the northern direction $(2.9710 \ldots 4.4208)$ indicate intensive accumulation processes of heavy metals in the soil under investigation. In all three directions, soil is characterized by a moderately hazardous category of pollution; the level of toxic compounds exceeds the MAC, but does not exceed the translocation factor. All territory investigated in these three directions can be used for cultivating agricultural crops, but strict sanitary control of the production is an indispensable prerequisite.

The essence of this research is that in previous studies by a number of scientists (Kharytonov et al., 2008, 2016, 2020), the physiological features of sprouts of red radish roots showed the ability of seeds to respond to exogenous chemical influences during germination. This is primarily reflected in the difference in the length of the root sprouts, in particular, the decrease in biometric indicators in response to the increased negative impact.

Based on the determination of the morphometric parameters of the test objects, it was found out that their growth and development were inhibited (Fig. 4). Germination of radish seeds on contaminated soil decreased by $69 \%$ and $68 \%$, respectively.

Phytotoxic effect was determined as a result of the investigation into soil condition and measurements of radish sprouts.

Northwest wind is the most recurrent wind flow (17\%) in the area under investigation. The level of inhibition of growth processes in the southeastern direction (Fig. 5a) was high $(67.16 \pm 2.820 \%)$ at a distance up to $750 \mathrm{~m}$ and above the average level at a distance up to $1750 \mathrm{~m}-43.50 \pm 0.806 \%$, and only at a distance of $2000 \mathrm{~m}$, the situation improved and the 'average' level of toxicity was recorded.

In the eastern direction (Fig. 5b), winds are also often recurrent, as in the southeastern. The recurrence of the west wind for 
Table 4. Dependence of soil phytotoxicity on the distance from the source of emission.

\begin{tabular}{|c|c|c|c|c|c|c|}
\hline Indicator & $\begin{array}{c}\text { Domain of function, } \\
\text { Max } \leq \mathrm{x} \geq \text { Min }\end{array}$ & Equation of dependence & $\begin{array}{c}\text { Pearson correla- } \\
\text { tion coefficient, } \\
\mathbf{r}\end{array}$ & $\begin{array}{c}\text { Statistical sig- } \\
\text { nificance, } \\
\mathbf{p}\end{array}$ & $\begin{array}{c}\text { Determination } \\
\text { coefficient, } \\
\mathbf{r}^{2}\end{array}$ & $\begin{array}{c}\text { Correlation } \\
\text { significance }\end{array}$ \\
\hline Southeastern & $9.46 \leq \mathrm{x} \geq 0.44$ & $\mathrm{y}=139.0879-2.8481^{\star} \mathrm{x}$ & -0.6667 & 0.0353 & $\begin{array}{c}\text { Negatively } \\
\text { high }\end{array}$ \\
\hline Eastern & $9.11 \leq \mathrm{x} \geq 0.34$ & $\mathrm{y}=175.7996-4.551^{\star} \mathrm{x}$ & -0.7655 & 0.0099 & 0.5845 & $\begin{array}{c}\text { Negatively } \\
\text { high }\end{array}$ \\
\hline Northeastern & $7.71 \leq \mathrm{x} \geq 0.31$ & $\mathrm{y}=120.0541-2.913^{\star} \mathrm{x}$ & -0.7023 & 0.0235 & 0.4932 & $\begin{array}{c}\text { Negatively } \\
\text { high }\end{array}$ \\
\hline Northern & $7.29 \leq \mathrm{x} \geq 0.33$ & $\mathrm{y}=155.7511-4.3398^{\star} \mathrm{x}$ & -0.8636 & 0.013 & 0.7457 & $\begin{array}{c}\text { Negatively } \\
\text { high }\end{array}$ \\
\hline
\end{tabular}

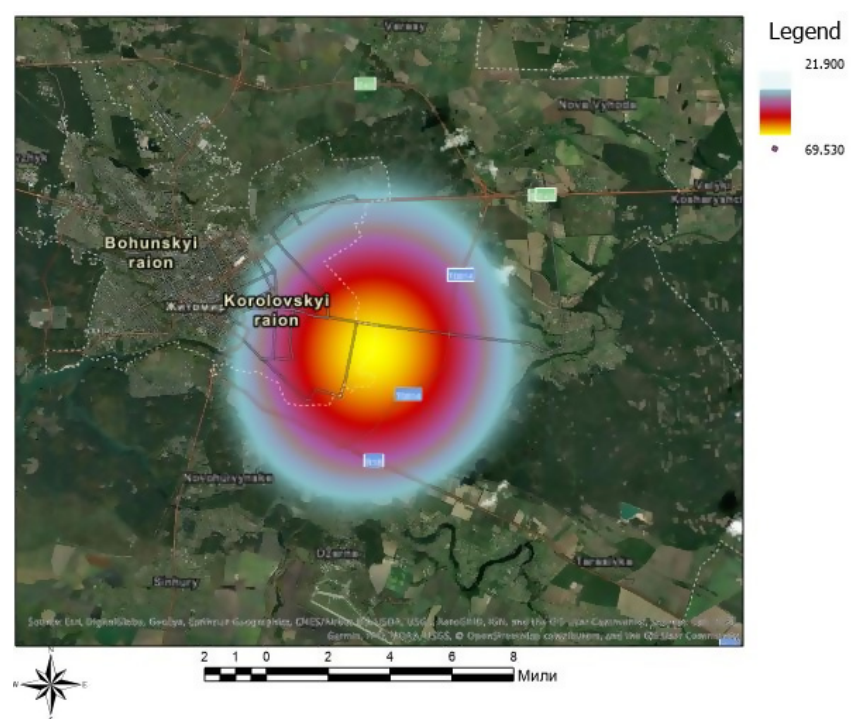

Fig. 6. Interpolation of soil phytoxicosis indices of the territory of the eastern industrial hub in Zhytomyr (Ukraine) with the IDW method.

the territory is $16 \%$, and this is also reflected in the mosaic of the contamination of soil cover. A high toxicity level was recorded up to a distance of $250 \mathrm{~m}(64.77 \pm 1.482 \%)$, and compared to the previous direction, it was by $2.29 \%$ more. The soil at a distance up to $1500 \mathrm{~m}$ was found to be $49.07 \pm 7.597 \%$ above the average toxicity level, and the soil with average toxicity $(30.75 \pm 2.55 \%)$ was found at a distance up to $2000 \mathrm{~m}$.

For the northeastern direction (recurrence of southwestern wind $12 \%$ ), high soil toxicity was observed at a distance up to $750 \mathrm{~m}-58.82 \pm 4.2991 \%$, and above average level at a distance up to $1750 \mathrm{~m}-37.842 \pm 3.8608 \%$. Stabilization of soil cover to average toxicity level was noted only at a distance of $2000 \mathrm{~m}$, where it was recorded at about $28.20 \%$ (Fig. 5c).

In the northern direction (recurrence of southern wind $12 \%)$, high soil toxicity was observed at a distance up to $750 \mathrm{~m}$ - $56.38 \pm 4.5113 \%$, and above average at a distance up to 1500 $\mathrm{m}-38.46 \pm 1.2516 \%$. Stabilization of soil cover to average toxicity level was noted only at a distance from $1500 \mathrm{~m}$, where it was recorded at about $23.70 \pm 0.575 \%$ (Fig. $5 \mathrm{~d}$ ).

Inhibition of the growth processes of radish roots identified the toxicity level of the technogenic substrates tested as average and above average (Table 4).
Thus, the results of interpolation of soil phytoxicosis indices on the territory of the eastern industrial hub in Zhytomyr (Ukraine) with the IDW method show that in all the investigated directions, there are inverse close correlations between the distance from the source of emission and the indicators of soil phytotoxicity (Fig. 6). This indicates that the activity of the Eastern industrial hub has a significant negative effect on the vegetation cover of phytocenoses bordering the territory where industrial activities are conducted.

\section{Conclusion}

Eastern industrial hub has about 45 industrial enterprises of food, light, chemical, metallurgical, engineering, and other industries. Such high concentration of diversified industrial enterprises in a small area affects the state of the surrounding ecosystems. There are now 85 stationary sources of polluting emissions at these enterprises, and rotary kilns mainly contribute to the atmospheric pollution making about 4600 tons of inorganic dust a year.

The investigation of dust accumulated on the surface of leaves showed that it contains high concentrations of $\mathrm{Mn}, \mathrm{Cr}, \mathrm{Pb}, \mathrm{Ni}$, and $\mathrm{Cu}$. Over the last ten years, emissions of heavy metals with nonlocalized dust have amounted to: $\mathrm{Mn}-33,158, \mathrm{Zn}-3687, \mathrm{Ni}-$ $4604, \mathrm{Cu}-7736, \mathrm{Cr}-42,364 \mathrm{~kg}$. Sixty-two percent of the annual emissions of heavy metals, which amounts to $5752.5 \mathrm{~kg}$, fall on the period of active vegetation of plants (April-September).

The highest rates of total soil contamination were observed in the southeastern direction. In almost all directions, two particularly critical zones were noted. This is an area at a distance of 200-250 m, where the maximum index of soil saturation with elements was indicated, which is indicative of intensive processes of accumulation of pollutants. In this area, there were the maximum concentrations of cuprum, which is mainly dispersed in the form of coarse particles, and thus settles closer to the source of emission. The second critical area in this direction is the area at a distance of $1.5-2 \mathrm{~km}$ from the source of emission. This indicates that fine particles, which contain a large amount of manganese, zinc, and plumbum, are of key importance in soil contamination in this direction. The indexes of soil saturation with elements indicate intensive accumulation processes.

Analysis of the phytotoxicity of the territory using the bioindicative method confirmed that the activity of the Eastern industrial hub has a significant negative impact on the vegetation cover of the phytocenoses bordering the territory where industrial activities are conducted. 


\section{References}

Baderna, D., Lomazzi, E., Pogliaghi, A., Ciaccia, G., Lodi, M. \& Benfenati E. (2015). Acute phytotoxicity of seven metals alone and in mixture: Are Italian soil threshold concentrations suitable for plant protection. Environ. Res., 140, 102-111. DOI: 10.1016/j.envres.2015.03.023.

Berestetskyi, O.A. (1971). Metodu opredelenyia toksychnosty pochv. Kyiv: Urozhai.

Cao, Q., Hu, Q.H., Khan, S., Wang, Z.J., Lin, A.J., Du, X. \& Zhu Y.G. (2007). Wheat phytotoxicity from arsenic and cadmium separately and together in solution culture and in a calcareous soil. J. Hazard. Mater., 148(1-2), 377-382. DOI: 10.1016/j.jhazmat.2007.02.050.

Dayton, E.A., Basta, N.T., Payton, M.E., Bradham, K.D., Schroder, J.L. \& Lanno R.P. (2006). Evaluating the contribution of soil properties to modifying lead phytoavailability and phytotoxicity. Environ. Toxicol. Chem., 25(3), 719-725. DOI: 10.1897/05-307r.1.

Dzhura, N.M., Romanyuk, O.I., Gons`or, Y.An., Cvilinyuk, O.M. \& Terek O.I. (2006). Vikoristannya roslin dlya rekulstivaciï Iruntiv, zabrudnenih naftoyu i naftoproduktami. Ekologiya ta Noosferologiya, 17(1-2) 55-60.

Favas, P.J., Pratas, J. \& Prasad M.N.V. (2012). Accumulation of arsenic by aquatic plants in large-scale field conditions: opportunities for phytoremediation and bioindication. Sci. Total Environ., 433, 390-397. DOI: 10.1016/j.scitotenv.2012.06.091.

Fedoniuk, R.H., Fedoniuk, T.P., Zimaroieva, A.A., Pazych, V.M. \& Zubova O.V (2020). Impact of air born technogenic pollution on agricultural soils depending on prevailing winds in polissya region (NW ukraine). Ecological Questions, 31(1), 69-85. DOI: 10.12775/EQ.2020.007.

Fedoniuk, T.P., Fedoniuk, R.H., Romanchuk, LD., Petruk, A.A. \& Pzych V.M (2019). The influence of landscape structure on the quality index of surface waters. Journal of Water and Land Development, 43, 56-63. DOI: 10.2478/jwld-2019-0063.

Fedonyuk, T.P., Fedoniuk, R.H., Zymaroieva, A.A., Pazych, V.M. \& Aristarkhova E.O. (2020). Phytocenological approach in biomonitoring of the state of aquatic ecosystems in ukrainian polesie. Journal of Water and Land Development, 44, 65-74. DOI: 10.24425/jwld.2019.127047.

Fedorchak, E. (2020). Influence of pollution on photosynthesis pigment content in needles of picea abies and picea pungens in conditions of development of iron ore deposits. Ekológia (Bratislava), 39(1), 1-15. DOI 10.2478/eko-2020-0001.

Gusev, A.S. \& Vashukevich N.V. (2016) Soil estimation and land use in the impact zone of metallurgical factories (Middle Urals, Russia). Wschodnioeuropejskie Czasopismo Naukowe, 8(6), 45-50.

Gyekye, K.A. (2013). An assessment of toxic in urban soils using garden cress (Lepidium sativum) in Vasileostrovsky Ostrov and Elagin Ostrov, Saint Petersburg, Russia. Journal of Geography and Geology, 5(4), 63. DOI: $10.5539 /$ jgg.v5n4p63.

Jandová, V., Bucková, M., Hegrová, J. \& Huzlík J. (2020). Effect of chlorides from chemical de-icing agents on soil contamination depending on the distance from road and its effects on living organisms. Ekológia (Bratislava), 39(4), 301-309. DOI: 10.2478/eko-2020-0024.

Jośko, I. \& Oleszczuk P. (2013). Influence of soil type and environmental conditions on $\mathrm{ZnO}, \mathrm{TiO} 2$ and $\mathrm{Ni}$ nanoparticles phytotoxicity. Chemosphere, 92(1), 91-99. DOI: 10.1016/j.chemosphere.2013.02.048.
Kharytonov, M.M., Kroik, A.A., Vinnichenko, O.M. \& Shupranova L.V. (2008) Air pollution assessment related with large industrial city activities. In I. Barnes \& M.M. Kharytonov (Eds.), Simulation and assessment of chemical processes in a multiphase environment (pp. 385-393). Netherlands: Springer. DOI: 10.1007/978-1-4020-8846-9_31.

Kharytonov, M.M., Benselhoub, A., Klimkina, I., Bouhedja, A., Idres, A. \& Aissi A. (2016). Air pollution mapping in the Wilaya of Annaba (NE of Algeria). Mining Science, 23, 183-189. DOI: 10.5277/msc162315.

Kharytonov, M.M., Stankevich, S.A., Titarenko, O.V., Weisssmannová H.D., Klimkina, I.I. \& Frolova L.A. (2020). Geostatistical and geospatial assessment of soil pollution with heavy metals in pavlograd city (ukraine). Ecological Questions, 31(2), 47-61. DOI: 10.12775/EQ.2020.013.

Lozanovskaya, I.N. (1998). Ekologiya i ohrana biosferyi pri himicheskom zagryaznenii. Higher School.

Maňkovská, B. \& Oszlányi J. (2010). Long term air pollution studies (1990$2005)$ in báb research sites using the moss biomonitoring technique. Ekológia (Bratislava), 29(1), 40-46. DOI: 10.4149/ekol-2010-01-40.

Martin, D., Vollenweider, P., Buttler, A. \& Günthardt-Goerg M.S. (2006). Bioindication of heavy metal contamination in vegetable gardens. For. Snow Landsc. Res., 80(2), 169-180.

McBride, M.B. \& Martínez C.E. (2000). Copper phytotoxicity in a contaminated soil: remediation tests with adsorptive materials. Environ. Sci. Technol., 34(20), 4386-4391. DOI: 10.1021/es0009931.

Miroshnychenko, M.M. \& Krivitska I.A. (2016). The phytotoxicity of soils in urban landscapes of Mariupol city. AgroChemistry and Soil Science, 85 6-11. DOI: 10.31073/acss85-01.

Romanchuck, L.D., Fedonyuk, T.P. \& Fedonyuk R.G. (2017a). The model of landscape vegetation influence on the mass transfer processes. Biosystems Diversity, 25(3), 203-209. DOI: 10.15421/011731.

Romanchuck, L.D., Fedonyuk, T.P. \& Khant G.O. (2017b). Radiomonitoring of plant products and soils of Polissia during the long-term period after the disaster at the Chornobyl Nuclear Power Plant. Regulatory Mechanisms in Biosystems, 8(3), 444-454. DOI: 10.15421/021769.

Romanchuk, L., Fedonyuk, T., Pazych, V., Fedonyuk, R., Khant, G. \& Petruk A. (2018). Assessment of the Stability of Aquatic Ecosystems Development on the Basis of Indicators of the Macrophytes Fluctuating Asymmetry. Eastern-European Journal of Enterprise Technologies, 11(94), 54-61. DOI: $10.15587 / 1729-4061.2018 .141055$

Rudin, S.M., Murray, D.W. \& Whitfeld T.J. (2017). Retrospective analysis of heavy metal contamination in Rhode Island based on old and new herbarium specimens1. Applications in Plant Sciences, 5(1), 1600108. DOI: 10.3732/apps. 1600108

Yusypiva, T. \& Miasoid H. (2019). The state of bio-ecological characteristics of the one-year shoots of robinia pseudoacacia L. under the conditions of industrial pollution. Ekológia (Bratislava), 38(3), 240-252. DOI: 10.2478/ eko-2019-0019.

Zymaroieva, A., Zhukov, O., Fedonyuk, T. \& Pinkina T. (2020). The spatio-temporal trend of rapeseed yields in ukraine as a marker of agro-economic factors influence. Agronomy Research, 18(Special Issue 2), 1584-1596. DOI: $10.15159 /$ AR.20.119.

Zymaroieva, A., Zhukov, O., Fedoniuk, T., Pinkina, T. \& Vlasiuk V. (2021) Edaphoclimatic factors determining sunflower yields spatiotemporal dynamics in northern ukraine. OCL - Oilseeds and Fats, Crops and Lipids, 28 , 26. DOI: $10.1051 / \mathrm{ocl} / 2021013$. 